\title{
The Legal System for Credit Cards in Jordan
}

\author{
Ahmed Adnan Al-Nuemat \\ Al-Balqa Applied University, Salt, Jordan \\ Email:Ahmed_alnuemat@yahoo.com
}

How to cite this paper: Al-Nuemat, A. A (2017). The Legal System for Credit Cards in Jordan. Beijing Law Review, 8, 171-190. https://doi.org/10.4236/blr.2017.82010

Received: March 27, 2017

Accepted: June 23, 2017

Published: June 26, 2017

Copyright (C 2017 by author and Scientific Research Publishing Inc. This work is licensed under the Creative Commons Attribution International License (CC BY 4.0).

http://creativecommons.org/licenses/by/4.0/

\begin{abstract}
As a widely used banking service and application, credit cards have gained popularity in the last few years. They have broadened in techniques, impressions on clients and consumer transactions. Owing to the fact that masses are utilizing this facility, credit cards have become more popular, especially in Jordan. The lawmakers of the country have not yet updated the legal system according to the ongoing advancements through special laws. Such an update would pave the way for legal protection. This is an ongoing process, and people are currently experiencing legal dilemmas owing to the unlawful use of credit cards.
\end{abstract}

\section{Keywords}

Credit Card, Legal System, Civil and Penal Protection, Jordan

\section{Introduction}

In the field of business, credit cards provide advanced payments and fulfilment, which is the key feature of business deals. In the past, banknotes or coins were used to deal, so people created a better alternative for this process. This was done in order to avoid any potential damage or theft and to make the process of transfer easy. By issuing credit cards, the economic field has an extra participant-the bank-and this helps with the payment (Sawalha, 2011: p. 3).

From a global perspective, credit cards have proved vital to business transactions. In 1982, Jordan was provided with its first magnetic cards with Petra cards, which were issued by Petra Bank. After that, Cairo Amman Bank introduced Cairo cards. A limited liability company, Visa Jordan, founded in 1998 with an association of the banks in Jordan, introduced the first model of its kind in the Middle East. This shows the ease for global organizations to invest capital in Jordan (Khalil, 2000: p. 56). There are many disadvantages of using credit cards in Jordan, like the unavailability of special rules for the purpose of managing transactions, besides the lack of related precedents for credit cards. 
The reason behind this article is the lack of a sound legislation mechanism in Jordan related to credit cards. Hence, our goal is to extensively explain the contract-based associations that are formed with the use of credit cards. It also points out the consequences of their misuse. Based on this, the article is divided into three sections. The first explains the concept of credit cards, their characteristics and the different kinds. The second section describes the legal implications of utilizing credit cards because these legal aspects are the basis of every contract-based association involving credit cards. Finally, the last section gives insights into the penal and civil liability for the misuse of cards and the consequences, along with suggestions for updating the legislation.

\section{Definitions, Characteristics and Types of Credit Cards}

In this section, the author explains the characteristics and different sorts of credit cards. After every type has been differentiated, the author attempts to define the legal aspects of credit cards.

\subsection{Definitions of Credit Cards}

Credit cards are defined in many ways. Based on strictly technical terms, a credit card is a rectangle card made of plastic or paper issued by a bank or financial institution with the customer's name, the customer's account number and the bank's name printed on it. It is designed to compensate a purchase value to a merchant or for fulfilment. It is designed to be protected against tampering (Salem, 1995: p. 10).

To elaborate, another definition says that a credit card has the name and official logo of the issuance institution, along with the name, signature and account number of the client. The holder has the right to withdraw cash from ATMs or to utilize the card as a compensation tool for the services or goods offered by merchants or organizations. Its shape is rectangular and it is made of plastic. Moreover, its purpose is to provide security for a small amount of money in commercial deals (Sawalha, 2011: p. 5; Omar, 2003: p. 695).

It is important to point out that the aforementioned explanations are focused on the materials of the cards, not on the information encrypted on them. They also do not specifically mention the idea behind their creation.

Thematic explanation describes credit cards as a device that is used to pay for the services and goods purchased by customers by compensating for their values. This compensation is issued by the bank (Saad, 2005: p. 37; Saleem, 2010: p. 127).

On the basis of the above, credit cards can be referred to as fulfilment cards that enable cardholders to acquire services and goods and to provide compensation, as mentioned in the contract between the cardholder and the issuer (bank) (Basala, 1995: p. 2).

As a result, credit cards can be explained as a tool that focuses on the reliable relationship between the bank and the customer. This relies on the fact that the cardholder is permitted to utilize an amount of credit by the bank, dictated by the ceiling financial conditions and other conditions. (Saudi, 2001: p. 17) 


\subsection{Features of Credit Cards}

1) A credit card can be regarded as a credit and compensation device, owing to the fact that the owner of the card can use it for their financial commitments regarding service providers and merchants. This is done by not withholding the cash. Because it is a credit device, the issuer pays the value of the services and purchased items that are acquired by the owner. Consequently, the compensation is provided according to the contract (Saeed, 2009: p. 315).

2) On the basis of the tripartite deal, a credit card cannot be used to complete a transaction between the merchant and the holder, the issuer and the merchant, or the holder and the bank. Separate deals are signed between these groups, in which the rights and obligations are assigned separate from the other deals. For instance, the concluded deal between the holder and the issuer would not be similar to the one that would be signed with the merchant (Kilany, 2004: p. 509; Aljahny, 2005, p. 29).

3) Confidence and solvency are offered to the cardholder via a credit card. The card implies that the holder has the power to be solvent and secure in transactions. The client is represented by the bank in the face of the service providers and merchants. They rely on the bank upholding its promise to pay the agreed amount. This amount is committed by the cardholder while contracting with the merchants. The bank also puts its faith in the client, as they are offered a credit card after thorough investigation of their financial stability. Accordingly, it can be said that profit, security and credit are the foundation of credit cards (Al Talahmah, 2004: p. 178).

4) The deal that takes place between the cardholder and the bank is the basis of the possession of a credit card. The deal is based on a set period, after which the card is completely discarded and a new one is made. However, if the cardholder, the issuer ends the deal, the holder must not keep or use the card. The bank has the autonomy to cancel a credit card, while the holder has the right to not use a card and to return it (Al Baghdadi, 2006: p. 70).

5) As stipulated by the merchant, the bank receives a commission and interest. This happens because purchasing payments are needed urgently, along with the credit offered to the cardholder (Barham, 2010: p. 135; Aldwy, 2010: p. 55).

\subsection{Different Categories of Payment Cards}

There are many reasons why payment cards differ from one another. Standard golden and silver cards are available. Each of them has a different time limit and characteristics. In the matters of dealing clearance, worldwide, regional and national cards are present. Magnetic, laminated and smart cards are the three main physical types (Alalaby, 2005: p. 49).

With respect to payment cards, there are three main types. This careful categorization is explained below.

\subsubsection{Debit Cards}

It is vital that the cardholder already has a current account with the bank that issued the card, as this card type is considered a compensation tool. It cannot be 
used as an all-purpose credit tool, as the amount is deducted right away. In this situation, the bank makes sure that the balance of the holder's account is not lower than the purchasing amount, and that is why it is called a debit card (Alalaby, 2005: p. 53).

Soon after that, the bank subtracts the purchase amount from the client's account. This is done after the instruction has been sent to the bank by the merchant. To explain further, the bank sends an account statement to the cardholder at the end of every month. The statement is based on the cash that is withdrawn via ATMs, amounts paid via card to merchants and any deposits made. This card type requires the holder to deposit funds so that they can be managed by the bank. However, if the client pays more than their balance allows (going into their overdraft), the bank will ask the client for interest, as dictated by the card issuing deal (Alshoura, 2005: p. 10).

\subsubsection{Charge Cards}

These cards play the role of credit cards and fulfilment cards at the same time. The issuing authority does not require the holder to have an account with them because the issuer allows the cardholder to have a restricted ceiling for a limited amount of time. This implies that for the fulfilment of the payment of services or goods, the holder has a set time, which is why it is referred as a delayed fulfilment card (Alshoura, 2005: p. 10).

The bank will ask the cardholder for the total withdrawn value. This value is requested at the end of every month and must be paid within 25 to 40 days, as mentioned in the contract. In accordance with the concluded deal between the holder and the issuer, the former will be charged by the latter for late payments. (Musa, 2003: p. 1997; Saeed, 2009: p. 16).

\subsubsection{Credit Cards}

This card type permits the cardholder to buy goods or services on credit, paying back the bank later, and requires the holder to have an account with the issuing bank. It does not allow cash withdrawals via ATMs. The terms of credit are set by the bank (Alharby, 2006: p. 211).

\section{Legal Aspects of Credit Cards}

There have been various objections raised related to the legal aspects of credit cards. Some criticise the ideas of credit and fulfilment brought in by these cards. These aspects of credit cards set them apart from other ways of payment, as the association between the parties dictates. In order to adhere to the legal regulations that control these legal relationships, legal aspects must be recognized. The legal aspects have been recognized in various theories; some use the angle of commercial law mentioned below, while others incorporate civil codes.

\subsection{A Theory of Credit Cards}

\subsubsection{Debt Assignment Theory}

This theory involves accepting a debt on behalf of someone else; in this situation, 
this individual is now obligated to fulfill the responsibility of the debtor. (Jordan Civil Code) Debt assignment takes place by either cardholder with the bank or the merchant and the bank without any interference from cardholder, the idea may suit explaining banking card system. (Jordan Civil Code, Article 995) At the first instance, could be imagined that cardholder (debtor) has agreed under this contract with the bank to pay for the merchant (creditor), as the merchant (Creditor) has accepted in accordance to the contract concluded with the bank, as it is possible that transfer from the merchant whom agreed with the bank to fulfill from the debtor, hence the debtor who is cardholder has agreed under the contract and acknowledge by signing when purchase (Esaa, 2015: p. 538).

Owing to the fact that the legal aspects of credit cards contradict debt assignment theory, this theory is not applicable. The debit cannot be seized from the cardholder before the merchant has provided the credit card details and signed purchasing bill. There is no impactful effect of debt assignments on the debtor before the creditor's transfer of money (Esaa, 2015: p. 539).

\subsubsection{Authority Theory}

Jordanian lawmakers describe an authority as the owner of a nominated deal done in light of Rules 833 - 867. It is a deal whereby the assignor allows and permits an entity to work on their behalf for permitted and recognized acting.

The use of e-credits by corporate structures and merchants is justified. In this theory, the bank is allowed to pay the service value. Later, that same amount is subtracted from the assignor's balance; thus, the bank is the authorized and the cardholder is the authorizer (Aljboury, 1997: p. 113).

Upon analysis, many points have been raised. The authorizer is permitted to make withdrawals. This is only allowed when a payment has been lost or stolen or the assignor is undergoing judicial liquidation. It is plausible that the authorizer would object in this situation, as the bank does not have to connect the merchant to the cardholder (Nejam, 2013: p. 1163).

\subsubsection{Agency Fulfillment Theory}

The agent must fulfill the debt to the merchant, in light of the connection between the card issuer and the cardholder. This system is a reliable juridical grounding for the credit card mechanism. However, this obligation does not define the card issuer's rights; these are carried out via granted credit (Alharby, 2006: p. 226). The debt is the agent's responsibility, regardless of his association with the authorizer. It is also applicable when the deal is reversed (Radwan, 1990: p. 9).

Many counter-arguments to this theory have been presented. If it is stated that the legal foundation of the credit card mechanism is the agency in fulfillment, then the contractual association between the merchant and the bank is ignored because of the bank's obligation to the merchant. Then, the bank will provide the former with the amount without considering the connection between the cardholder and the bank (Alsanhoury, 1958: p. 870; Mansour, 2006: p. 412). 


\subsubsection{Bail Theory}

It is important that the principal provides compensation to the agent, as mentioned in Article 950 of the Jordanian Civil Code. It is the amount that the former is responsible for; this amount is sustained while they carry out their agency. Hence, the concluded deal can be defined as a bail deal between the merchant and the bank, while the latter provides confirmation for compensating purchase values to the merchant. Otherwise, it is paid by the cardholder. Regardless of the fact that the holder cannot fulfill the requirements, the bank provides the bills by default when they are provided to them in the form of a contract signed by the cardholder (Fakhry, 1984: p. 62).

\subsubsection{Loan Contract Theory}

A loan can be defined as the act of providing the possession of property or worthy items to a person under agreed conditions. The receiver is supposed to transfer an amount at the end of a deadline. The rules contain information about the amount to be paid, as mentioned in Article 636 of the Jordanian Civil Code. Keeping that in view, many have highlighted the connection between credit card issuer and cardholder, where the former offers an amount of cash in order to fulfill the latter's need. The bank also asks for repayment at the earliest time. In this relationship, they regard this information as the basis of the loan. Any faulty aspects in the possession of the borrower are not the responsibility of the loaner (Alharby, 2006: p. 218).

There has been disapproval with this, as it is not actually a loan. It builds its foundation on the mutual connection that is present between borrower and lender. A loan also does not foster relationships between other parties and the lender. On the other hand, a credit card transaction is dependent on a three-way connection among the cardholder, merchant and card issuer.

It can be said that a credit card is actually a fulfillment source with a unique ability. Owing to the fact that legal connections and multiple parties are managed by multiple contracts under credit cards, there is no connection with the theories (Maghrabi, 2003: p. 951). As a result, every legal connection designed will be investigated. For the purpose of providing credit cards, credit provisions are implemented for the contract between the cardholder and the bank. The sales contract is controlled by the cardholder and the merchant, as it represents the fulfilled debit assigned to the merchant by the cardholder. This implies that various deals are included in credit cards. These deals include offering a credit e-banking method and fulfillment after a contract has been concluded (Maghrabi, 2003: p. 951).

\subsection{Credit Card Parties that Originate the Legal Relationships}

A credit card has three primary relationships that originate from deals. This is explored by presenting the three groups within the contract-based connections.

\subsubsection{Connection between Card Owner and Bank}

The adherence contract is defined as the connection that binds the cardholder 
and the bank under the terms of a contract. The responsibilities of both groups, explanations of the issued card and the methods of use are mentioned in the contract. As the terms are provided for the client's approval or disapproval by the bank, this contract is an adhesion contract for the card owner. Considering this fact, it is true that the owner does not have the power to object to the contract. The completed card issuance application is investigated to avoid any case of non-reimbursement (Ahmad, 2005: p. 17).

It is possible for the bank to not validate an application that does not have validity. On the contrary, the matters are concluded by both cardholder and issuer. The cardholder has to provide proof of their capability as required (Al Amin, 2003: p. 467).

The name of the owner will be included in the contract if the applicant belongs to a corporate structure. The credit card will be used by the corporate body and the cardholder as dictated by the liability. The rules collectively apply to both entities (Al Amin, 2003: p. 467).

The roles of the bank and the cardholder in this whole process are mentioned below.

A. The duties of the bank:

1) The responsibility of the bank to provide the card: Along with the secret number, the bank is responsible for providing the cardholder with the credit card. The issuing authority must also maintain the policy of protecting everything (Tobia, 2000: p. 45).

2) The role of the bank in fulfilling debits as a result of the card use: It is mandatory for the authority to pay purchasing values. These values are designated for merchants and provided by card owners via their cards. An agreed boundary is set for purchasing values. If a payment goes beyond the limit, then the issuing body is permitted to acquire that money with an added interest rate. Nonetheless, the authority must provide for every purchasing contract undertaken by the cardholder (Tobia, 2000: p. 45).

3) Sending monthly statement to cardholder stating amount due by using the card for purchasing as well as cash withdrawals, cardholder is responsible for them. The objecting time limit could be a month or 15 days, as decided. If no disapproval is shown, it is assumed that the cardholder has agreed to all conditions of the statement (Shaheen, 2001: p. 170).

4) Issuance of card and opening credit: The credit tool allows the transfer from the owner's account to a payment card or payment subtractions. With the help of enquiries regarding the solvency of the client and confirmations regarding their status, the bank will decide whether or not the payment of opened credit will be offered. This information is provided prior to the possession of credit. The owner receives the credit card via the e-banking method, and it can be used after it has been sent (Fawzy \& Al-Qadoumi, 2005: p. 118).

5) The signature of the cardholder is protected and used as a confirmation on bills (Fawzy \& Al-Qadoumi, 2005: p. 118).

B. The responsibilities of the cardholder: 
1) To guarantee that information is correct, the issuer of the card must be provided with every important personal detail of the cardholder, like residential and work addresses, place of contract, and other data. This makes altering information in the future a lot easier. The bank can take away the card if the information lacks accuracy (Nazih, 2006: p. 78).

2) The owner of the card is responsible for use, restoration and issuing fees, along with commissions removed by the bank authority or any cost of the card's use, including the prices of telexes and telegrams (Shawkat, 2007: p. 54). The owner is also responsible for the compensation of every amount withdrawn through the card in cash through ATMs or another facility. It also includes purchase values received by sellers through the bank (Musa, 2003: p. 2003).

3) The card should not be in the possession of any person other than the cardholder. It is necessary that the holder should keep the card along with its secret number and manage them carefully, as their ID is recognized by the authority. Moreover, only the holder can approve another's use of the card, with the issuing body's approval (Al-Kaliouby, 1999: p. 473).

4) Via cash withdrawals from the ATMs of banks, the card should be used for the right reasons. In order to enjoy the full advantages, the owner must use it for buying goods and services provided by different sellers within the provided credit limit. The holder must not spend beyond the set limit; otherwise, the bank can revoke the contract. The bank will demand reimbursement for the money spent by the owner (Nazih, 2006: p. 94-95).

5) The issuing authority must be provided with the card at the earliest time after the limit has been exceeded. Usually, the period comprises a year or more (Sawalha, 2011: p. 111).

\subsubsection{Association between Merchant and Bank}

The merchant acts as a client of the card, whereas the bank acts as the card issuer. The two entities are bound by an independent contract, known as the contract of the merchant or the contract of the supplier. These expressions are synonymous, as they assert that the card issuer (the bank) holds a commitment for compensating the merchant for the purchase price agreed by the customer (the cardholder).

The contract formulated between the merchant and the bank is a type of adhesion contract in which the merchant (the customer) is not given the opportunity to confer its terms and regulations with anyone, as the customer for the card is chosen by the bank itself on the basis of the respect, morality and commercial reputation of the merchant. None of the heirs can proceed with this contractual agreement or pay money for property on behalf of the merchant, as this contract is specifically instituted on the merchant's superior moral and principled behaviour. If any person desires to adopt this contract, then they have to form a new contract with the bank (the card issuer), as the previous one will be automatically dissolved.

This contract is a form of compelled contract in this regard, as the merchant and the bank are bound in mutual responsibilities uniformly, and each is liable 
to the other. The merchant's bills, as a part of this responsibility, will be paid by the bank (the card issuer), whereas the merchant will have to comply with the instructions of the card issuer and recognize card transactions (Alhunais, 2008: p. 139).

\section{1) Responsibilities of the Card Issuer}

1. If the merchant agrees to the contract, then a credit card will be provided to the merchant for the agreement of the rules and regulations of the contract. Card issuer must attract customers holding credit cards. As a consequence, a card issuer grants the sanction of credit cards to customers agreeing to a contract in terms of obtaining goods and services (Alqudah, 1999: p. 406).

2. For processing card transactions, all the relevant equipment and machines must be endowed to merchants, inclusive Point of sale (POS) special invoices for sales recording, credit card machine printers and credit card terminals, along with other necessary supplies and instruments for card integration procedures. The merchant is provided with all this equipment upon shipment, and they will have to be returned if the card issuer demands them or the contract ends (Maghrabi, 2003: p. 952).

The card issuer (bank) is liable to carry out functions of buying values on account of merchant and making payments on account of credit cards on behalf of the contract. Likewise, the card issuer is obligated to make all payments drawn upon a credit card by the merchant. Nevertheless, if the balance of customer was exceeded or customer's insolvency, card issuer is committed before the merchant with persuasion to agreement between them, where this agreement is devoid of defenses that might be held by customer toward the merchant. The bank shall not claim against the merchant through defenses before cardholder's transaction be made as a claim for lack of balance or insolvency or customer's objection on fulfillment (Musa, 2003: p. 890).

The undertaking signed by the merchant and the card issuer enables both of them to fulfill their commitments. For the card issuer, the commitment is to pay the merchant under whatever conditions, whereas the merchant is liable to act on behalf of the card issuer's instructions, checking the signature of the client on the check/bill, ensuring the ID of the client only within the holder's limit for the purpose of card validity and bill sealing, as the issuer also holds the right to refuse payments to merchants in particular cases, as mentioned below (Barham, 2010: p. 156):

A. The processes or terms stated in the contract and its clauses are inserted to make sure that both the merchant and the card issuer do not violate each other's rights; however, if the merchant does not act within the clauses stated in the contract, it will be considered breach of contract, and this will enable the card issuer to disregard and disagree with what the merchant desires on account of a card.

B. If the merchant draws more card proceedings than the amount settled on in the contract, the card issuer can proceed with the overdraft amounts by attaining a specific term from the merchant. On the other hand, if the mer- 
chant already has permission to cross the balance limit through agreement, the merchant merely needs to state the permit number on the cheque or any bill before adding their signature to it.

3. Card issuer is complied with submitting lists including counterfeit, lost or stolen cards to the merchant, where it liable to undertake this compliance at once to prevent using those cards, meanwhile, to disclaim its liability for any related dealing once the merchant being notified about loss of counterfeiting (Maghrabi, 2003: p. 955).

4. Banks must perform certain advertising through commercial campaigns, promotions, brochures and hoardings about the discharge and offer of the credit card to notify people about its advantages and characteristics, as well as the facilities provided by the bank for card issuance. Likewise, stores and merchants must be familiar with the card's acceptance as a form of payment by their clients (Maghrabi, 2003: p. 955).

\section{2) Merchant's Obligations}

1. The merchant accepts credit cards that are utilized legally and under restricted guidelines that should be strictly followed, based on an agreement with the issuer to accept them. In addition, the merchant deals with the cards of customers instead of cash; if not, the bank will not renew the contract with the merchant on cardholder terms. To all cardholders, the merchant should offer amenities and services at a reasonable cost, which should be free of bias and the card issuer's commission (Almahdi, 2003: p. 759).

In some particular cases, the merchant has the right to reject the utilization of credit cards, as the contract with the issuer states that cards can be rejected if the reasons and excuses are rational. Nevertheless, the contract will be terminated in cases of irrational rejection.

2. Before taking the required actions, the merchant should verify the validity of the card. This can be done through checking the expiry date, as cards expire after a certain time period. In case of ignorance of this significant matter, the merchant will be held responsible. Afterwards, the salesperson checks the owner's ID and then swipes the card in the machine in order to get the printout of the slip. They then fill in the required information and verify the cardholder's signature to compare it with the sample signature present on the card. Moreover, the salesperson needs to check that the data regarding the bill of sale is clear. After verifying all this information, the salesperson should return a copy of the bill and supply the amenities to the cardholder (Almahdi, 2003: p. 760).

3. The merchant is legally responsible for paying commission. The commission is visible in the contract between the merchant and the issuer. A particular level of interest exists for each undertaken transaction through the card, including the membership fees remunerated by the merchant (Radwan, 1990: p. 124).

4. Authorization for using credit limited cards means to actually define the utilized amount of the card which is enough to cover cardholder's purchase. 
Verification can be done through calling the leading or authorization centre of the concerned bank so as to confirm whether they have approved the overall transaction or not. The merchant will be accountable for the risk due to the exceeded limit of the card; the bank only allows amounts within the defined limits (Alhunais, 2008: p. 155).

5. The merchant should resolve the conflicts with the clients: Any disputes rose between the merchant and cardholder regarding the concluded contract. For instance, in cases of vulnerabilities in amenities or mismatches between bought and supplied merchandise, the merchant takes complete accountability because the issuer is not directly associated with this quarrel; their role is only to provide both parties with vital and concerned information regarding the clash in order to provide proof and then solve the dispute (Alhunais, 2008: p. 155).

\subsection{Association between Merchant and Cardholder}

The association between the cardholder and the merchant is dependent upon the nature of the contract, whether it is a sale or service agreement, which differs from any other contract between credit card parties. From the jurisprudence perspective, the membership contract (concluded between the customer and the bank), as well as the merchant or supplier contract, does not affect this agreement. In addition, it is easy to identify the legal nature of this association, as it is evaluated from the nature of the deal between the two parties, including the privileges and compulsions for each party. All provisions, terms and obligations of the contract are included in the Jordanian Civil Code, excluding one subject: the payment method when the association between the cardholder and the merchant is defined in a trade agreement (Shawkat, 2007: p. 56).

The card owner will not be free of debt until and unless the merchant receives their payment from the bank. If the bank refuses to pay, which is termed the defection of the card, the merchant upholds all legal privileges to demand payment from the card owner. As mentioned, the association between the cardholder and the merchant is autonomous as compared to the affiliation between the issuer and the merchant. Hence, the validity of amenities does not influence the bank's obligations towards the merchant, which is the main concern behind the disputes between merchants and card owners (Awad, 1988: p. 665).

The sale or service contract between the card owner and the merchant is a two-sided agreement, and the following section lists the reciprocal obligations.

\section{- Cardholder's Commitments}

1) In order to enable the merchant to collect on a bill, the card owner needs to sign the purchasing bill. In addition, the merchant should be satisfied. According to jurisprudence, the customer's role won't be limited by signature on the bill presented by merchant or e-signature by keying in secret number on the machine, the actual fulfillment comes from the card issuing bank. Recent developments have shown that the issuing bank should give the reclamation directly to the merchant; if the transaction is rejected by the bank, the customer is required 
to pay (Alshoura, 2005: p. 50).

2) Cardholder shall not make an order to the bank requiring non-repaying bills submitted by the merchant, because bank's obligation is emanated from concluded contract between them which is merchant contract, if the merchant is complied with terms of contract and using card regulations, the cardholder is not involved in this contract (Maghrabi, 2003: p. 965).

3) The merchant needs a valid and real card from the card owner. If it turns out that the card is illegal or invalid (e.g. expired or counterfeit), the cardholder is held accountable for the crime of fraud committed by using a fake card (Alhmoud, 1999: p. 76).

\section{Credit Cards' Legitimate Safety}

The wide distribution of credit cards results in illegal activities. Due to this, various legal complications and an abundance of banking industry information can be caused. Hence, effective civil and penal protection should be provided in cases where credit cards cause legal problems. Subsequently, this section is split into two areas. The first deals with the civil protection for credit cards, whereas the second explains the penal protection for credit cards.

\subsection{Civil Protection for Credit Cards}

In general, the civil obligation in terms of a source is referred to contractual liability emanated from contractual commitment which based on tort and damage, the causal relationship between the tort and the damage, tort liability based on the action and harm and causal relationship in Jordanian law which raised when a person harms another one. Liability with various types is reforming the damage resulted by in execution of the obligation through compensation.

In the case of misuse of the card by the cardholder, issuing authority, merchant or others, then civil protection for the credit card can be activated. Therefore, the following subsections discuss civil liability for card owners (on the part of holder, issuer and merchant), which is classified into three points. A fourth additional point revolves around uncivil liability.

\subsubsection{Cardholder's National Accountability}

The associations among the credit cardholder, the issuing authority and the merchant are autonomous pledged relationships in which the compulsions are enforced by contracts. The contractual liability shall be imposed on both the merchant and the issuer of the card in cases where the cardholder breaks any of these obligations. The most vital obligation that the card owner has is accountability and trying their best not to go beyond the limit granted by the card issuer. If they exceed the card limit, the card owner will be held civilly liable to confront the card issuer if the agreement states not to exceed the highest limit of this guarantee (Saad, 2005: p. 117).

If an agreement to not exceed the allowed limit does not exist, then the cardholder will be held accountable towards the merchant in order to examine the 
deduced contract in cases where the card owner performed in good faith when the limit was exceeded (Radwan, 1990: p. 160).

However, the card owner will perform under bad faith while undertaking their liabilities if they are aware of the exceeded credit card amount. The card issuer has the complete right to withdraw the card from the cardholder due to the loss of confidence between the cardholder and the card issuer, as the card shows the original identity of its holder. Moreover, the card issuer can claim paid amounts and compensation for any harm that takes place due to the usage of the card by the card owner after the breach of the contractual obligations (Radwan, 1990: p. 160).

The accountability enforced by the deduced contract between the card issuer and the owner is that the cardholder is compelled to return the card after the termination of the contract. If the card owner keeps on utilizing the card even after the expiry date, civil liability will take strict actions regarding the amounts utilized on the card. The fundamental feature of this situation is the idea of unfair amelioration on the part of the cardholder because of the termination of the agreement between the cardholder and the issuer (Maghrabi, 2003: p. 950).

The card owner will be held accountable if their card gets stolen or lost. These cases will be considered negligent and careless. It is the foremost duty of the cardholder to protect the card.

In the opinions of some legislators, the card owner should not be disclaimed until and unless they are unable to show proper evidence (i.e. they did not verify and match the signature on the card). if merchant is obligated to verify the signature on the bill can avoid cardholder civil liability to report the issuer with lost and stolen cases, in order to take actions to inform other merchants about such cards through periodic submitted lists including cancelled, expired, stolen and lost cards, as the cardholder is actually liable for used amounts through the card between the period of it being stolen or lost and delivering notification to the issuer (Maghrabi, 2003: p. 950).

\subsubsection{Card Issuer's National Accountability}

Actions like ceasing bill reimbursement to a merchant are taken by the card issuer if the merchant breaks their commitments until and unless the liabilities specified in the agreement are complied with. Accordingly, if the merchant gets harmed, like a card issuer does not assume their role well, causing non-reimbursement, the merchant has the privilege to complain about compensation on the basis of contractual liability (Jordanian Civil Code, Article 256).

If a card was lost or stolen but the merchant was not informed, the issuing authority is accountable for paying the bills of the merchant. Hence, the issuer should pay merchant financial request, as the contract forces the issuer to compensate the amounts.

In circumstances such as unmatched, damaged or incomplete merchandise and products, the issuer is obligated to reimburse the merchant, as the association occurs between the merchant and the cardholder. This is related to relative principle of the contract impact, since the legal relationships eliminated from 
using credit cards are independent contractual relationships. Consequently, the issuer is the third party in this situation between the merchant and the cardholder.

\subsubsection{Merchant's National Accountability}

Due to the contract between the merchant and the issuer, the merchant is supposed to accept cards for recompense. If the merchant refuses cards, the issuer has a complete right to claim recompense. This behaviour can affect the issuer, as it will make cardholders reluctant to use their cards, resulting in the issuer losing interest and benefits. Moreover, in this case, the claim for compensation will be on the basis of contractual liability, as the merchant did not fulfill one of their core duties mentioned in the deduced contract with the issuing authority (Altaweel, 2000: p. 272).

The cardholder's ID should be verified by the merchant, who contracted to accept cards, and this can be done through matching the signature on the bill with the signature on the card. If the salesperson ignored that and dispatched a bill with a fake signature to the issuer, the issuer has the right to decline repayment through civil liability.

Furthermore, if the merchant dispatched unsigned bills to an issuer, they would be held accountable. Signatures are the most substantial part of the bills, as the bills act as an order issued for fulfillment. The worth of the cardholder's signature in the merchant's contract cannot be denied (Altaweel, 2000: p. 272).

The merchant has to deal with the prevention of card misuse, as it is the merchant's responsibility to keep an eye on the list of lost, stolen or cancelled cards, which is submitted to merchants on a frequent basis.

In order to complete sales transactions, the merchant shall maintain all devices granted by the issuer. If the merchant does not maintain them, they are required to recompense the issuer.

\subsubsection{National Accountability of Others}

Whoever utilizes a lost or stolen card, excluding the cardholder, is accountable for this illegal behaviour and is liable for damages to the legal owner on the grounds of tort liability, which clearly states "do not harm others", as the unauthorized user is not party to any of the deduced contracts concerning the card.

\subsection{Penal Protection for Credit Cards}

Such misuse and fraud cannot be avoided; however, policymakers must offer penal protection for credit cards due to the rising number of cardholders, particularly for business transactions.

The best way to implement criminal liability is through financial punishments for illegal deeds with the cards. This is discussed in two main respects. The first deals with criminal liability for the card's parties; the second deals with criminal liability for others who are not included in the credit card's contracts.

\subsubsection{Accountabilities of the Cardholder}

The medium of communication for discussing this is fundamental parts. The 
first part revolves around the cardholder's criminal liability, along with clarification of the credit card's illegal usage by the credit card owner. On the other hand, the second part talks about the merchant's criminal liability.

\section{1) Cardholder Exploiting the Credit Card for Illegitimate Activities}

This refers to where the card owner utilizes the card even after it has been terminated by the issuing bank, has expired or has been lost. In these situations, the most crucial duty of the card owner is to return the card to the issuer. The question arises here is: is misusing the card a crime against the issuer?

In light of Article 422 of the Jordanian Penal Code', "Anyone who obtains any property, item or document which comprises of a responsibility or discharge of debt, relying on trust and to be used and returned, or to be kept or to achieve a certain work-paid or unpaid-and he/she denies receiving such item or replaces or consumes or refuses to hand it over, he/she shall be penalized by custody from two months to two years and by a fine from ten to one hundred dinars (JD10-100)". This article highlights some vital criminal elements and exploitation by the cardholder.

Another question that arises is: is it a felony or fraud to utilize an expired or cancelled card?

When the issuer makes the decision to cancel it, they are supposed to inform the card owner, as they need to return the card. If the cardholder utilizes the card even after the issuer's cancellation decision, then they will face the following consequences (Al Baghdadi, 2006: p. 187):

1. Merchants should avoid dealing with the mentioned card when the issuer informs the merchant about the annulment of the card. If not, the merchant needs to tolerate the outcomes of this deed because the card owner cannot be accused of fraud.

2. If the issuer does not inform the merchant regarding the cancellation of the card, then the merchant will consider it authorized. As a consequence, the availability of the credit which led him to accept the card. In this situation, the card owner is accused of a felony, due to which he is subjected to Article 417 of the Jordanian Penal Code 2 , which specifies the penalty as "imprisonment from three months to three years and by a fine from one hundred to two hundred dinars (JD100-200)".

${ }^{1}$ Penal Code No. 16/1960 and its amendments, as last amended by the Law No. 8 of 2011.

${ }^{2}$ Article 417 of the Jordanian Penal Code "1) Whoever makes another person deliver to him/her any moveable or immoveable property or any documents which includes an undertaking or a remission from dept and he/she takes control of it through deception: a) Through the use of deceptive means which makes the victim falsely believe the existence of a false project or instance or to raise the victim's hopes that he/she will gain profits or that he/she will retrieve the amount of money taken from him/her, or the existence of a dep't bond. b) Through the disposition of a moveable or immoveable property while knowing that he/she has no capacity to do so. c) Through the use of false name or a wrong capacity. The perpetrator shall be punished by imprisonment from three months to three years and by a fine from one hundred to two hundred dinars (JD100-200). 2) The penalty shall be doubled if the crime is committed in one of the two following instances: a) If the perpetrator is a person who is entitled to issue shares and bonds or any other financial papers related to a company or a project or any industrial or commercial establishment. b) If the act is committed based on the promise to secure an employment or work in a public administration. 3) The same penalty shall be applicable on attempts to commit any of the misdemeanors stipulated in this article". 


\section{2) Cardholder Exceeding the Credit Limit}

The card owner is normally liable if they exceed the credit amount that was mentioned in the contract with the bank when conducting a transaction. However, if the credit amount is not declared on the card, the merchant should call the issuer's authority centre to ask about the permitted amount. In this case, the merchant shall be liable for the exceeded amount because the card owner did not cheat the merchant, as the merchant was aware of the real credit limit. According to various legislators, the card owner is not criminally liable if the merchant called the issuer in order to check the covered amount, as the issuer will pay the dealer the value then later refer to the holder for the exceeded amount, depending upon the contractual liability, as the holder showed an original, legal and active card without any fraud (Khalil, 2000: p. 115; Habashna, 2006: p. 66).

\subsubsection{Third-Party Criminal Accountability}

Third Parties are those who did not issue credit cards in their names by the issuer, as well as there are many offensive cases against credit cards by others, these offensives are considered a crime punished by law, such crimes are committed by others against cards are 1-Forgery crimes 2-Larceny (Al Baghdadi, 2006: p. 195):

\section{1) Forgery}

In Article 260 of the Jordanian Penal Code, forgery is defined as "the intentional alteration of the truth in the facts, which is meant to be proved by a document or certificate, thereby causing physical or mental or social harm". In light of this description, forgery crimes are classified into three elements (Albahar \& Alezzawy, 2003: p. 1023):

1. Place of crime is editing that is applied on credit card, because it contains information and data able to be forged as editing in expression mean about legal relationship between two persons covering rights and liabilities as well as law punishes for changing facts.

2. Physical element: In Articles 260 and $262^{3}$ of the Jordanian Penal Code, this element is the modification of the truth by altering the credit card's data.

3. Moral element: General and private criminal intention should be provided for the accused person, as general intention is represented in the knowledge of the accused person with all forgery elements. The felonious intention of the accused individual needs to be confirmed. For instance, altering the truth in documents is recognized by law as evidence of forgery, followed by recent or possible damage against an individual or the world. Private intention is using the forged document in purpose(s) that is prepared for that pursue.

In light of the aforementioned content, if an individual alters a credit card, they are accountable for forgery, which is specified in the Jordanian Penal Code;

${ }^{3}$ Article 399 of the Jordanian Penal Code "1) Any public official who commits physical forgery while executing his/her official duties, whether through the misuse of a signature or stamp or finger print or through him/her signing a forged signature or through making a document or certificate or with what he/she adds or omits in the content of a document or a certificate, such public official shall be punished by temporary imprisonment for no less than five years. 2) The penalty shall not be less than seven years if such a forged document is of the type to be used until there is a claim that it is a forged one. 3) The provisions of this article shall be applicable when wholly or partially destroying the document". 
therefore, they should be punished under Article 262.

\section{2) Larceny}

According to Article 399 of the Jordanian Penal Code, theft can be described as taking away the moveable property belonging to another without their consent. ${ }^{4}$ In terms of credit card theft, it is the use of funds possessed by others with the intention of acquisition of the funds themselves or to acquire property with them. The elements of theft are as follows (Nejam, 2013: p. 1167):

1. Physical element: The thief takes physical possession of the card from its actual holder without approval.

2. Place of crime: the card itself: a credit card is a moveable asset owned by others that is used for transfers.

3. Moral element: Theft is an intention felony that is done on purpose. It can only be done by the presence of an illegal intent, which is displayed in the mixture of facts and desire.

Subsequently, if anyone illegally acquires the credit card of another person and has the intention to own it, then they have committed a felony. According to Article 399 of the Jordanian Penal Code, the reasons behind this illegal conduct (e.g. the accused not knowing the secret number) cannot change the reality that the theft has been done and the legislated elements have been fulfilled.

Therefore, the thief will be accused under Article 407 of the Jordanian Penal Code, which states: "1) anyone who obligates a theft offence apart from the ones approved in this segment (for instance, pick pocketing) shall be punished by imprisonment from three months to one year. 2) In case a car was the subject of a theft offence, then the penalty shall not be less than the minimum limit stipulated in paragraph 1 of this article and it is not permissible to replace this penalty by a fine". A stolen credit card clearly shows that the accused committed the crime of fraud through theft from the actual holder of the credit card, considered a type of scam.

In light of Article 417 of the Jordanian Penal Code, if the merchant provides the false card user with goods and services after being persuaded of the legitimacy of the card and the credit being approved accordingly, this means that this user lied, which is among the fraud methodologies that constitute fraud. Consequently, he will be liable for fraud and honesty felonies.

\section{Conclusion}

This research revolves around the legal nature of the credit card. Our motive was to deliver the most authentic and vital information regarding the usage of credit cards, which we have accomplished by classifying this information into three main segments. The first segment dealt with the definition of a credit card, as well as the primary purpose. The second segment highlighted the parties in${ }^{4}$ Article 399 of the Jordanian Penal Code: “1) Theft is taking away the moveable property belonging to another without his/her consent. 2) The phrase 'taking away property' means eliminating the owner's powers over the property through moving it from its original place; if it was attached to an immoveable property, it happens through severing it completely and moving it". 
volved in the system of credit cards. The final section covered civil and criminal liability for credit card parties and others.

As mentioned previously, the credit card is a resource of fulfillment, meaning that merchants do not have to rely on cash payments. Due to this, the card owner can lower their risk, as they do not need to carry cash. Moreover, the merchant is less likely to refuse card payments, and much easier to process compared to cheque payments. The use of credit cards offers protection to merchants through guarantees from the credit card company. Furthermore, using a credit card reduces the risk of theft and loss of assets such as cash, which makes it a more attractive proposition to a large number of customers.

Credit cards legal nature or basis that imposes legislate argument is stated diversity of parties and legal relationships networking that combines them together. This has been elaborated through exploring numerous theories to understand the legal aspects, allowing us to identify that a special contract exists between the cardholders and the card issuers. These contracts are prepared with mutual agreement and joint objectives: in other words, to benefit all parties with the use of cards across a range of functions and circumstances.

With the advent of credit cards, under Jordanian law, specific provisions have been introduced into the Civil Code to protect the rights of all the parties associated with the cards. The Penal Code of the country also gives certain protective rights to safeguard from any criminal liability, but they are often inadequate. We propose several recommendations for filling the gaps in the current legislation. These have been created by examining the fundamental and significant attributes of the card system. These are as follows:

1) The provisions and regulations of credit card systems and their functioning in the banks must be standardized by Jordanian law in pursuit of safeguarding the rights of each party.

2) Regulations for relationships, resulted by using credit cards, shall be included in commercial laws to solve arguments between researchers; to identify the nature of such relationships and to be a ground to stand on by them.

3) Each party involved must have their important obligations clarified by the formulation of elaborated specifications. There should be specific obligations described regarding the payment mode and card processing for the merchants, along with providing appropriate guidance regarding criminal and civil liabilities for all the parties involved in utilizing the credit card system. This law would particularly safeguard cardholders engaged in contractual agreements with banks.

4) Economic and legal research should lead to the creation of informative brochures about credit cards to fill the gap in the current literature and to ensure all members of the Jordanian community are aware of how they should be used. This way, each individual would have knowledge about different card types and the responsibilities associated with each.

\section{References}

Ahmad, I. (2005). Civil and Criminal Protection for Payment Cards (Credit Cards). 
Alexandria: Al Dar Al Jamy'ia.

Al Amin, A. S. (2003). Credit Card. In E-Banking Conference. Dubai: Dubai Chamber of Commerce.

Al Baghdadi, K. (2006). The Illegal Use of the Credit Card-Civil and Criminal Liability. Master's Thesis, Jordan: University of Jordan.

Al Talahmah, K. (2004). Financial and Banking Legislation Theoretically and Practically. Amman: Dar Al Esraa for Publication.

Alalaby, A. (2005). Legal System of Credit Cards. Beirut: Alhalabi Publications.

Albahar, M., \& Alezzawy, A. (2003). Credit Card and Legal Influences. In E-Banking Conference (Vol. 3). Dubai: Dubai Chamber of Commerce.

Aldwy, I. (2010). Ecommerce-Applied Study of Libraries. Riyadh: King Fahd National Library.

Alharby, M. (2006). Fiqh Relation between Card Issuer and Holder. Law Journal, 30.

Alhmoud, F. (1999). The Legal System for Credit Cards. Amman: Dar Al Thaqafah.

Alhunais, A.-J. (2008). Criminal Protection for Magnetic Credit Cards against Forgery. Journal of Economic and Legal Sciences, 24.

Aljahny, H. (2005). Civil Liability for Illegal Use of Fulfilment Cards and Regulations for Them. Master's Thesis, Amman: Amman Arab University.

Aljboury, Y. (1997). A Brief Explanation of Jordanian Civil Law: The Influences of Personal Rights. Irbid: Alhamada Center for Publication.

Al-Kaliouby, S. (1999). Commercial Paper, According to the Trade Act No. 17 of 1999 (3rd ed.). Cairo: Dar Al-Nahda.

Almahdi, N. (2003). General Theory of the Credit Card System. In E-Banking Conference (Vol. 2). Dubai: Dubai Chamber of Commerce.

Alqudah, F. (1999). The Obligations Resulting from the Use of the Credit Card. Journal of Darasat, 26.

Alsanhoury, A. (1958). Explaining the Civil Code. Beirut: Dar Al Ahiba for Arab Heritage.

Alshoura, J. (2005). The Issues of E-Payment. Master's Thesis, Amman: Amman Arab University.

Altaweel, N. (2000). Banking Business and Related Crimes. Amman: Dar Wael.

Awad, A. J. A. (1988). Legal Aspects of Bank Transactions. Cairo: Dar Al-Nahda Al-Arabia.

Barham, N. (2010). The Provisions of Ecommerce Contracts (3rd ed.). Amman: Dar Althaqafha.

Basala, R. (1995). The Crimes of Credit Cards. Alexandria: Dar Alshorooq.

Esaa, N. (2015). Electronic Credit Card. Scientific Journal for the Faculty of Law, University of Babylon, 7.

Fakhry, R. (1984). Credit Card from a Legal Point. Journal of the Fatwa and Legislation Department, 4.

Fawzy, A. K., \& Al-Qadoumi, A. K. (2005). The Impact of Jordanian E-Transactions on Banking Transactions. Master's Thesis, Amman: Amman Arab University.

Habashna, J. (2006). Criminal Protection of Fulfilment Cards. Master's Thesis, Mu'tah: Mu'tah University.

Khalil, E. (2000). Criminal Protection of the Fulfilment Cards. Amman: Dar Wael for Publication. 
Kilany, M. (2004). Commercial Legislation and E-transactions. Amman: Dar Wael for Publication.

Maghrabi, T. (2003). Legal Aspects of Credit Cards. In E-Banking Conference (Vol. 3). Dubai: Dubai Chamber of Commerce.

Mansour, M. (2006). Traditional, Electronic and International Sailing Regulations and Consumer Protection. Alexandria: Dar Alfikr Aljam'y.

Musa, A. (2003). Banking Cards-Definitions, Types and Nature/E-Business. In Conference between Sharia and Law. United Arab Emirates University, Faculty of Sharia and Law.

Nazih, M. (2006). Legal Nature of E-Credit Cards and Civil Liability Raised. Cairo: Dar Al-Nahda Al-Arabia.

Nejam, M. (2013). Criminal Liability for Illegal Use of Credit Card. In E-Banking Conference. Dubai: Dubai Chamber of Commerce.

Omar, M. (2003). The Definition of Credit Cards and the Resultant Relationships Due to Use between Sharia and Law. In E-Banking Conference. Dubai: Dubai Chamber of Commerce.

Radwan, F. (1990). Fulfilment Cards. Maktabat Al Jalaa, Al Mansoura.

Saad, A. (2005). Dealing with Credit Cards in Islamic Sharia. Mutah Journal, 20.

Saeed, A. (2009). Legal Protection Methods for Ecommerce Transactions. Beirut: AlHalabi Legal Publications.

Saleem, N. (2010). E-Commerce Regulations (3rd ed.). Amman: Dar Althgafha.

Salem, O. (1995). Criminal Protection of the Fulfilment Cards. Cairo: Dar Al-Nahda Al-Arabia.

Saudi, T. (2001). Credit Cards and the Legal Basis of the Relationships Resulting from Using Them. Cairo: Dar Al-Amin for Publication.

Sawalha, M. (2011). Credit Cards. Beirut: Al Haditha Company for Publishing.

Shaheen, R. (2001). Banking and Financial Legislation. Amman: Dar Al-Baraka Publisher.

Shawkat, F. (2007). Banking Credit Cards in Islamic Fiqh. Master's Thesis, Al-Najah National University.

Tobia, P. (2000). Credit Cards and Contractual Relationships. Beirut: Al Halabi Legal Publications.

\section{Legislations}

Jordan Civil Code from 1st January 1977, Law No. 43/1976 of May 23rd, 1976.

Penal Code No. 16/1960 and its amendments, as last amended by the Law No. 8 of 2011. 
Submit or recommend next manuscript to SCIRP and we will provide best service for you:

Accepting pre-submission inquiries through Email, Facebook, LinkedIn, Twitter, etc. A wide selection of journals (inclusive of 9 subjects, more than 200 journals)

Providing 24-hour high-quality service

User-friendly online submission system

Fair and swift peer-review system

Efficient typesetting and proofreading procedure

Display of the result of downloads and visits, as well as the number of cited articles Maximum dissemination of your research work

Submit your manuscript at: http://papersubmission.scirp.org/

Or contact blr@scirp.org 